\title{
Interaction Between Circulation of the Estuary of the James River and Transport of Oyster Larvae
}

\author{
Evon P. Ruzecki \\ Virginia Institute of Marine Science \\ William J. Hargis Jr. \\ Virginia Institute of Marine Science
}

Follow this and additional works at: https://scholarworks.wm.edu/vimsbooks

Part of the Oceanography Commons

\section{Recommended Citation}

Ruzecki, Evon P. and Hargis, William J. Jr., "Interaction Between Circulation of the Estuary of the James River and Transport of Oyster Larvae" (1989). VIMS Books and Book Chapters. 33.

https://scholarworks.wm.edu/vimsbooks/33

This Book Chapter is brought to you for free and open access by the Virginia Institute of Marine Science at W\&M ScholarWorks. It has been accepted for inclusion in VIMS Books and Book Chapters by an authorized administrator of W\&M ScholarWorks. For more information, please contact scholarworks@wm.edu. 


\section{Estuarine}

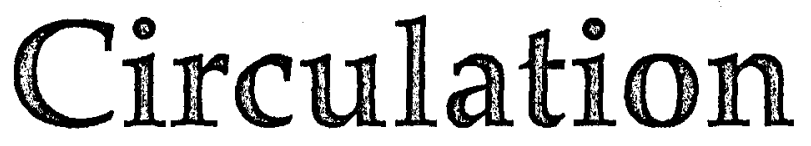

Edited by

\section{Bruce J. Neilson, Albert Kuo, and John Brubaker}

School of Marine Science

The College of William and Mary in Virginia,

Gloucester Point, Virginia

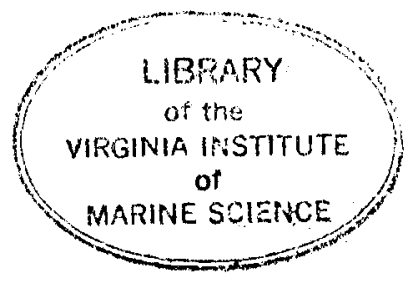

\section{Humana Press • Clifton, New Jersey}


(c) Copyright 1989 by The Humana Press Inc.

Crescent Manor

PO Box 2148

Clifton, NJ 07015

All rights of any nature whatsoever reserved.

No part of this book may be reproduced, stored in a retrieval system, or transmitted in any form or by any means, including electronic, mechanical, photocopying, microfilming, recording, computer database entry, or networking, or in any manner whatsoever without written permission from the publisher.

\section{Llbrary of Congress Cataloging-In-Publication Data}

Estuarine circulation.

(Contemporary issues in science and society) Includes index.

1. Estuarine oceanography. 2. Ocean circulation.

I. Neilson, Bruce J. II. Brubaker, John. III. Kuo, Albert. IV. Series.

GC97.E775 $1989 \quad 551.46$ '09 89-1725

ISBN 0-89603-155-1 


\section{Preface}

Estuaries exist along the edge of the oceans and seas, and are characterized by the dilution of sea water by inflowing fresher waters. The motion and interaction of these two types of water (fresh and salt water) determine the salinity distribution within the estuary and that, in turn, affects the organisms residing there. The purpose of this volume is to review the status of our understanding of estuarine circulation and how the circulation patterns affect living and nonliving resources in estuaries.

For many years, the primary paradigm for estuarine circulation was the two-layered net or nontidal gravitational circulation pattern first proposed by Dr. Donald Pritchard in his studies of the James River estuary. During the last decade or so, research has focused on the many variations about this theme and the factors that control the transport processes. Many of these aspects are covered in the initial papers in this volume. Water movement, of course, is of interest because it transports marine organisms, sediments, and pollutants. Estuarine circulation has a significant effect on estuarine food chains, and on the distribution and abundance of organisms, such as the American oyster, that are freely transported by the currents during larval stages. The intent is to bring together many of these topics in a single volume.

This volume is dedicated to Dr. Donald W. Pritchard, our colleague and friend, as was the conference held in Gloucester Point in January of 1985. The conference was organized as one means of recognizing his contributions to our understanding of the physical oceanography of estuaries. It was held in conjunction with the 1985 Charter Day exercises of the The College of William and Mary. At that time, Dr. Pritchard was awarded an honorary degree of Doctor of Science.

The editors would like to thank those who atttended the conference and especially those who made presentations, the authors of the 
$v i$

papers included in this volume, the many persons who reviewed these papers, and Mrs. Barbara Cauthorn, who prepared the final versions of the manuscripts.

Bruce J. Neilson

Albert Kuo

John Brubaker 


\title{
Contents
}

\author{
$v \quad$ Preface \\ vii Contents \\ ix Contributors
}

1 Estuarine Classification-A Help or a Hindrance, Donald W. Pritchard

39 Estuarine Flow Interaction with Topography; Lateral and Longitudinal Effects, K. R. Dyer

61 Headland Eddies in a Tidal Estuary, Nungjane C. Shi and Lawrence H. Larsen

87 Residual Currents in the Peconic Bays Estuary, Robert E. Wilson and Mario E. C. Vieira

97 The Response of Estuarine Circulation to Local Wind Events, K. P. Kiley and C.S. Welch

113 Computer Simulation of Wind-Driven Circulation in a Coastal Lagoon, Ned P. Smith

133 On Inter-Tidal Transport Equation, Ralph T. Cheng, Shizuo Feng, and Pangen $\mathrm{Xi}$

157 Excitation-Response Analysis of Estuarine Circulation, John M. Hamrick

183 A Tale of Two Estuaries: Columbia Bay, Alaska, and San Francisco Bay, California, Roy A. Walters

201 Time Scale Variations of Estuarine Stratification Parameters and Impact on the Food Chains of the Chesapeake Bay, Mary Altalo Tyler and H. H. Seliger 
235 The Influence of Physical Factors in Governing Temporal and Spatial Variations of Seston, Joseph A. Berg and Roger I. E. Newell

255 Interaction Between Circulation of the Estuary of the James River and Transport of Oyster Larvae, Evon P. Ruzecki and William J. Hargis, Jr.

279 The Role of Bottom Current and Estuarine Geomorphology on the Sedimentation Processes and Productivity of Wreck Shoal, an Oyster Reef of the James River, Virginia, Joseph T. DeAlteris

309 Considerations on Soft Mud Response under Waves, Peng-Yea Maa and Ashish J. Mehta

337 River Discharge and Sediment Deposition in the Upper Pamlico Estuary, Jonathan D. Phillips

351 Role of Models in Estuarine Flow and Water Quality Analysis, Tavit O. Najarian and Donald R. F. Harleman

375 Index 
INTRRACTION BETWEEN CIRCULATION OF THE RSTUART OF THE JAHES RIVER AND TRANSPORT OF OTSTER IARVAE*

\author{
Evon P. Ruzecki and William J. Hargis, Jr. \\ Virginia Institute of Marine Science \\ School of Marine Science/College of William and Mary \\ Gloucester Point, Virginia 23062
}

\begin{abstract}
Hydraulic model dye test results are examined to provide estimates of nontidal horizontal circulation and movement/retention of oyster larvae in the James River Estuary. Test conditions na intained a constant mean tide and average summer low freshwater discharge. It was assumed that movement of dye in the model would approximate movement of the planktonic (larval) stages of oysters (Crassostrea virginica) in the prototype. Test results were used to rank six dye release points (candidate brood stock locations) with respect to relative quantities of dye retained in areas of the model representing commercially important seed oyster beds during the period 20-40 tidal cycles after release (the time, after spawing, when oyster larvae will permanently attach to a suitable substrate). Under the test conditions, nontidal circalation in the model was similar to that found in a weak partially mixed estuary: upstream motion along the bottom and over the right hand shoals (looking upstream) and downstream motion olsewhero. The pattem was modified by cyclonic motion of surface waters in the upstrean and downstream reaches which increased residence time of material in the seed oyster bed region. Greatest retention
\end{abstract}

* Contribution No. 1410 from the Virginia Institute of liarine Science 
during the 20-40 tidal cycle period was from releases over upstream and right hand side shoals and is reflected in release point ranking.

\section{INTROD UCTION}

The James River has been, and remains, the most productive seed oyster producing estuary in Virginia's Chesapeake Bay System (Harg is 1966; Haven et a1.. 1978). Its success is believed due as much to its geomorphological features, salinity regime, and circulation patterns as to its biological characteristics, (Hargis, 1966; Hargis, 1969 ; Marsha11, 1954 ; Pritchard 1952; Wood and Hargis. 1971). A significant portion of that success has been attributed to the possibility that larvae producod downstroam are transported to the setting grounds upstream by the inward-moving deeper currents driven by gravitational circulation in the estuary. Thns, downstream beds of mature oysters are believed to have been the basis for a significant portion of the high-1evels of spatfall which, in turn sustained the high levols of seed oyster production, prior to 1960 (Haven et al , 1978). Since then production of spat, young recently-set oysters, has been extremely depressed. Consequently, the numbers of ' seed' oysters has also been reduced.

This decline in spatfall and seed oyster production coincided with massive mortalities of older oysters in the higher salinity portions of the Chesapeake Bay and its Virginia tributaries, including the James estnary, caused by an epizootic (epidemic) traced to a protozoan parasite. Commercial removals, made to avoid further losses, a 1 so took many. The resulting reduction in breeding-age oysters (or brood-stock) in the lower estunry is believod by some oyster scientists to have been the most likely canse of much of the decline in spatfall and, thus, soed in the upstream seedbeds (Andrews, 1983).

Scientists postulated that the most feasible method for rapid replenishment of market oyster production was to roplaco tho 'missing' larvae with thoso from speciallybred disoase-resistant broodstock. Work was begun on production of such diseaso-resistant oysters. Anticipating success in this ondeavor, we considered the question of where brood stocks should be placed to assure 
that their larvae would reach the setting areas in appropriate condition and numbers to establish themselves. A scalod hydraulic model of the entire tidal James River was employod to establish the locations in the lower James at which brood oysters should be placed. Accordingly, model experiments were designed to compare the distribution and the quantitative (numbers) and qualitative (time) fate of larvae, as simulated by dye, from selected reloase points (candidate sites for brood stock planting) in the lower estuary (Hargis, 1969 ; Ruzecki and Moncure, 1969). In this paper we review and further analyze the results acquired during our model studies in 1968 .

\section{METHODS}

\section{Experimenta1 Design and Procedures}

Six experiments using the flourescent dyes Pontacy 1 Brilliant Pink and Uranine were conducted in three runs of the James River Hydraulic model. The fluorescent charactoristics of these dyes permit separable detection of one in the presence of the othor when concentrations of each are in the parts per billion (ppb) range. Basic features of the experiments were:

1. Dye release points were sites which conld serve as primary larval sourcos and vere likely candidate sites for brood stock planting.

2. Regions of particular sampling interest wore the commercially important seed oyster beds shown in Figure 1.

3. Tida1-phase relationships of oyster spawning were unknown, therofore dye was released at a constant rate over one tidal cycle.

4. Mean time between spawning and attachment of resultant oyster larvae is fifteen days (Haven, ot a 1.. 1978). Thus sampling started twenty tidal cycles (approximately 10 days) after release and continued at alternating (but not consecutive) local slack water before ebb (SBE) and slack water before flood (SBF) for an additional twenty tidal cycles.

5. River discharge and source salinity matched the multiannual mean for late sumer, the primary spawning period in the James. 


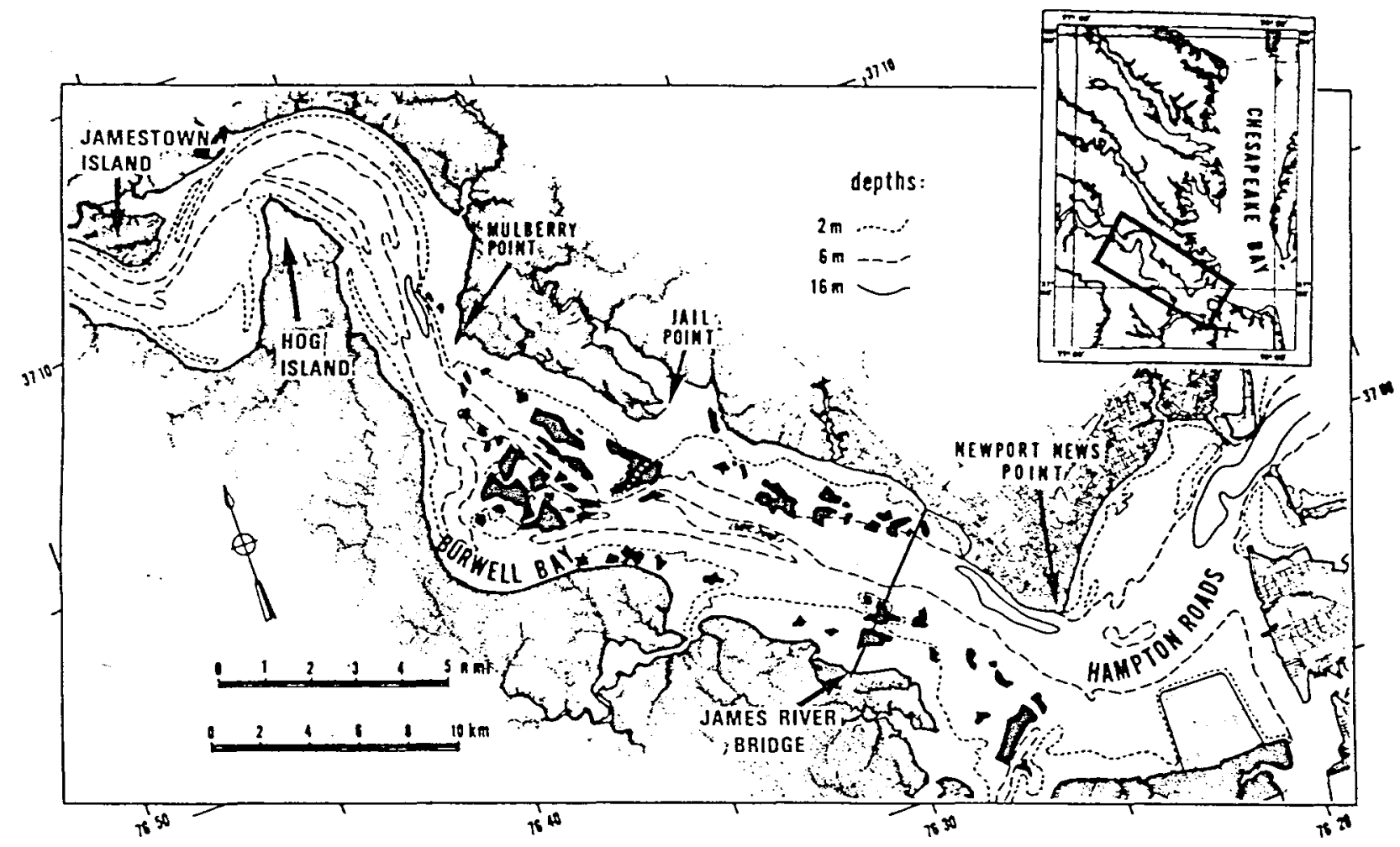

Figure 1. Chart of lower James River showing general bathymetry, location of public seed oyster beds and named features referred to in text. Inset shows location of James relative to Chesapeake Bay. 
6. At the conclusion of each model run, the distribution of each dye throaghout the model was de termined.

The James Rivor Ilydraulic Model was a distortod Froude model (USA COE, 1966) with length scaling factors of 1:1000 horizontal and 1:100 vertical and time scaled by 1:100. For each test repetitive moan tides with a prototype (real world) range of $0.76 \mathrm{~m}$. were simalated and freshwater discharge was constant to match prototype flows of $91 \mathrm{~m}^{3} \mathrm{~s}^{-1}$ at Richmond and a total of $27 \mathrm{~m}^{3} \mathrm{~s}^{-1}$ appropriately distributed among three major tributaries (Appomattox, Chickahominy and Nansemond Rivers). The salt water source salinity was maintained at $26 \mathrm{ppt}$.

These conditions were maintained for at least 140 tidal cyclos prior to dye injoction to insure steady state conditions in the model. Steady state was verified by measuring salinity at stations along the model axis every tenth SBE from startup to dyo injection.

Dye solutions were prepared by dissolving $5 \mathrm{~g}$ of dye in $100 \mathrm{~m} 1$ of distilled water and increasing the volume to $1200 \mathrm{ml}$ with water removed from the planned injection location in the model. Dye was injected at the model bed by pipetting $50 \mathrm{ml}$ aliquots twenty-five times during a tidal cycle, once every 18 seconds. Injection locations aro shown as numbered boxes in Figure 2 . Location 6 in the figure represents a brood stock region rendered unproductive by disease and associated commercial harvests.

A detailed description of sampling procedure was given in Ruzecki and Moncure (1969). Briefly, it was as follows: wator samplos rero pipottod from the model at 108 locations approximately $1 \mathrm{~m}$ apart in the rogion botreen Newport News Point and Jamestown Island (Fig. 1). From one to three samples were taken at each sation depending on water dopth. Samples were simultanoously siphoned from adjacent stations along paired cross-model transects with transoct sampling completed in less than 30 sec (equivalent to 50 min prototype time) at local slack water. Dye concentrations were determined with Turner 110 fluorometers. Each station was samplod fourteen timos during a modol run. 


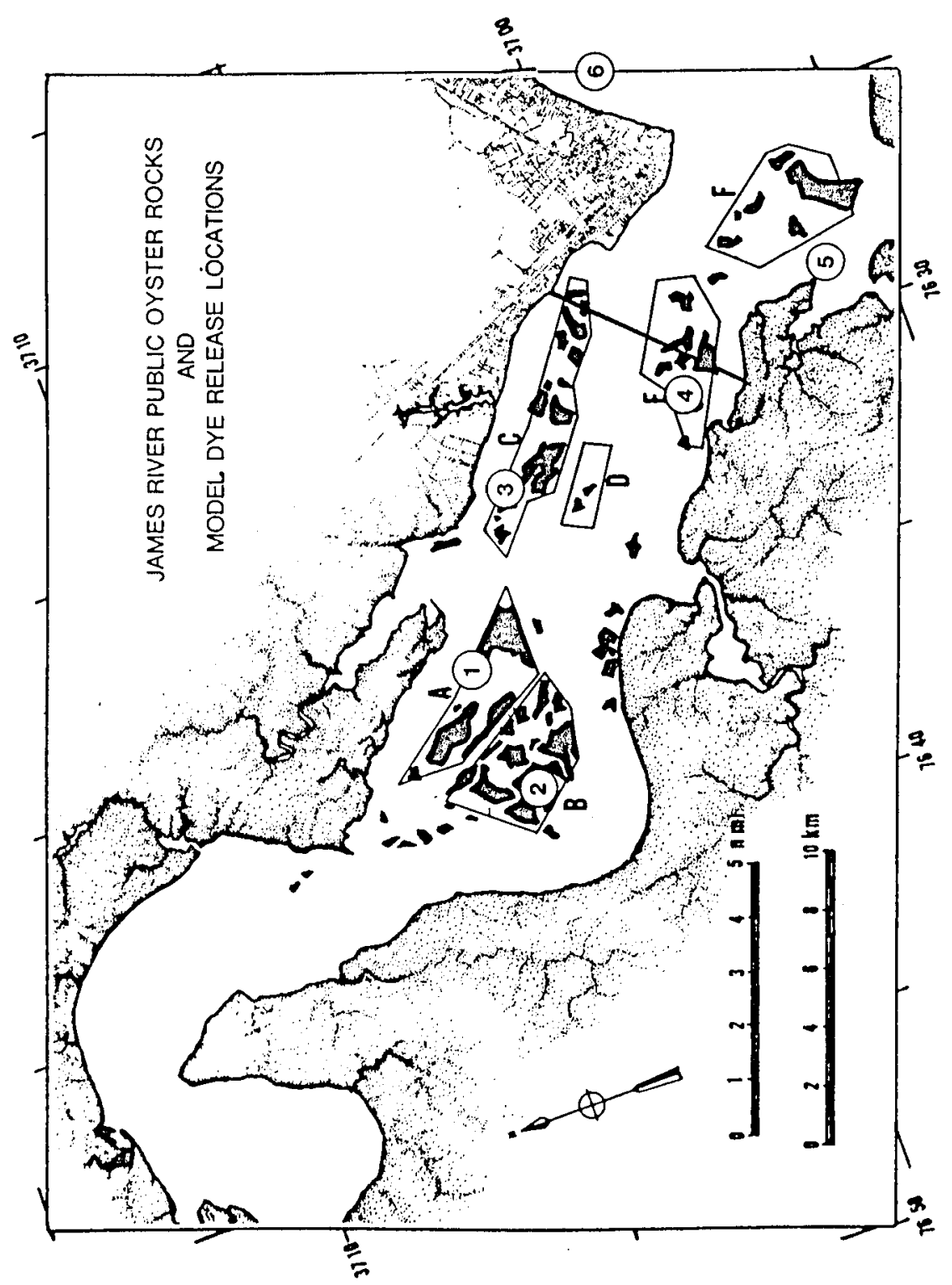

Figure 2. Selected areas representing James River pub1ic oyster rocks. Letter designations are: A, Wreck Shoal. B, Point of Shoals. C, Brown Shoal Reach. D, White Shoal. E, Naseway Shoal. F, Nansemond Ridge, boxed numbers indicate dye release locations. 
For Test $I$, dye was injected at Wreck Shoal and Point of Shoals (locations 1 and 2, Fig. 2) and first samples were obtained at SBF twenty cycles after injection. Successive samples were removed every third local slack water with final samples taken at SBE forty cycles after releaso.

The frequency and duration of sampling were altered for Tosts II and III based on dye movement and distributions observed during Test $I$. During Test II, dye was injected at Brown Shoal and Naseway Shoal (locations 3 and 4, Fig. 2) and first samples were obtained at SBE six cycles after injection. Successive samplos vere removed every fifth local slack water with final samples taken at SBF thirty-nine cycles after injection. For test III, dye was injected at Nansemond Ridge and llampton Fiats (locations 5 and $6, F i g .2$ ) and first samplos were removed at local SBF six cycles after injection. Successive samples were removed every fifth local slack water with final samplos taken at local SBE thirty-nine cyclos after injection.

At the end of each test, (SBE after tho final sample) the model was segmented by installation of dams at the following locations (see Fig. 1): the mouth of the James and major tributaries; between the bridge and Newport News Point; at oither end of Burwe11 Bay (Jail Point and Mulberry Point); off llog Island; and just upstream from Jamestown Island. Wator in segments was mechanically mixed and twenty random samples removed from each to establish a final inventory of dye.

\section{Data Treatmont}

Dye concentrations were treated in two ways:

1) Depth-integrated dye concentrations were determined for each sampling station for each sampling period as:

$$
\mathrm{CZ}=\Sigma \mathrm{C}_{\mathbf{i}} \Delta \mathrm{Z}_{\mathrm{i}}
$$

where $C_{i}$ was the measured concentration and $\Delta Z_{i}$ represented depth interval taken from surface to 
midway between the upper and mid level sample $\left(\Delta Z_{1}\right)$, from this lovel to midway between the mid level and near bottom sample $\left(\Delta Z_{2}\right)$ and finally to the bottom $\left(\Delta Z_{3}\right)$. The upper 1 imit of $\Delta Z_{1}$ was taken at near low water for SBF samples and increased upwards by $0.6 \mathrm{~cm}$ for $S B E$ samples to approximate tidal variations. Resulting data sets, named LARVAE, were taken to represent a time-dependent measure of oyster larvae per unit bottom area resulting from each reloaso and expressed as $\mathrm{mg}$ dye per $\mathrm{m}^{2}$ of model bottom.

2) Surface SBE concentrations were multiplied by the lesser of: total model water depth below MLW, or $6.0 \mathrm{~cm}$. Associated SBE concentrations had depth adjustments as above. Resulting data sets were named SPAT and taken to represent a timedependent measure of oyster larvae from each release which, when set would simulate spatfall on commercially worked bottoms (which, in the prototype, are found to water depths of $6 \mathrm{~m}$ ).

Both data sets were subjected to a SURFACE II interpolation routine (Sampson, 1975). Portions of SBE and SBF LARVAE data sets temporally adjacent to tidal cycle 30 were averaged and plottod as contour maps for each reloase. SPAT data were sumed over designated areas, (Fig. 2) which, in general, reprosent large aggregates of oyster rocks.

\section{Results and Discussion}

The results were used to:

1) Simulate density distribution of oyster larvac available throughout the soed bed areas at the time of maximum spatfall after late summer spawning,

2) rank reloase points as possible brood-stock sites,

3) rank the seed oyster bed regions as 'spat collectors' during the critical setting time, 
4) rank reloase points rith regard to temporal retention of dye within the soed oyster-producing portion of the estuary, and,

5) provide the most probable picturo of general circulation of waters in the James estuary undor oxperimental conditions.

\section{Dye Distributions Thirty Tidal Cycles After Release}

Average of LARVAE data sets (total dye in the water column) for thirty cycles after releaso are shown in Figures 3 , through $f$, as isopleths of mass of dye above unit model area $\left(\mathrm{mg} / \mathrm{m}^{2}\right)$. At this optimum setting time, the Wreck Shoa 1 release (Fig. 3,a) provided the maximum amount of dye over public oyster rock regions (see Fig. 2). All oyster rocks were covered with more than $10 \mathrm{mg} / \mathrm{m}^{2}$ and those in the Wreck Shoal and Point of Shoals regions ( $A$ and $B, F i g, 2$ ) were overlain by more than $25 \mathrm{mg} / \mathrm{m}^{2}$ of dye. Additionally, this roloase point provided the greatest quantity of dye retained within the primary seed oystex producing a rea betwoen Newport Nows Point and Mulberry Point (seo Fig. 1 for locations). The Point of Shoals and Brown Shoal Reach releases (release points 2 and 3) also resulted in relatively largo quantities of dye retained in the Newport Ners-Hulberry Point reach and 6 to $10 \mathrm{mg} / \mathrm{m}^{2}$ of dye over almost all public oyster rocks (Fig. $3, b$ and $c)$. When dye was released over southwestern shoal regions downstream from Burwel1 Bay (release points 4 and 5) and over Hampton Flats in Hampton Roads (release point 6), concentrations were substantially weaker over pub1 ic rocks and within the Newport News-Mulberry Point reach (Fig. 3,d, e and f). All plots of LARVAE data show higher values over deeper areas (compare Fig. 3 , a through $f$ with bathymetry shown in Fig. 1) which, we feel is due to integration over the total water column. This method of data treatment suggests cyclonic motion in the Burwell Bay region (particularly evident in Fig. 3,c) which may be roal or an artifact. Nonetheless, anking of release points relative to resulting distributions of dyo 30 cycles after release would, in general, coincide with the sequencing of Figures $3, a$ through $f$. 

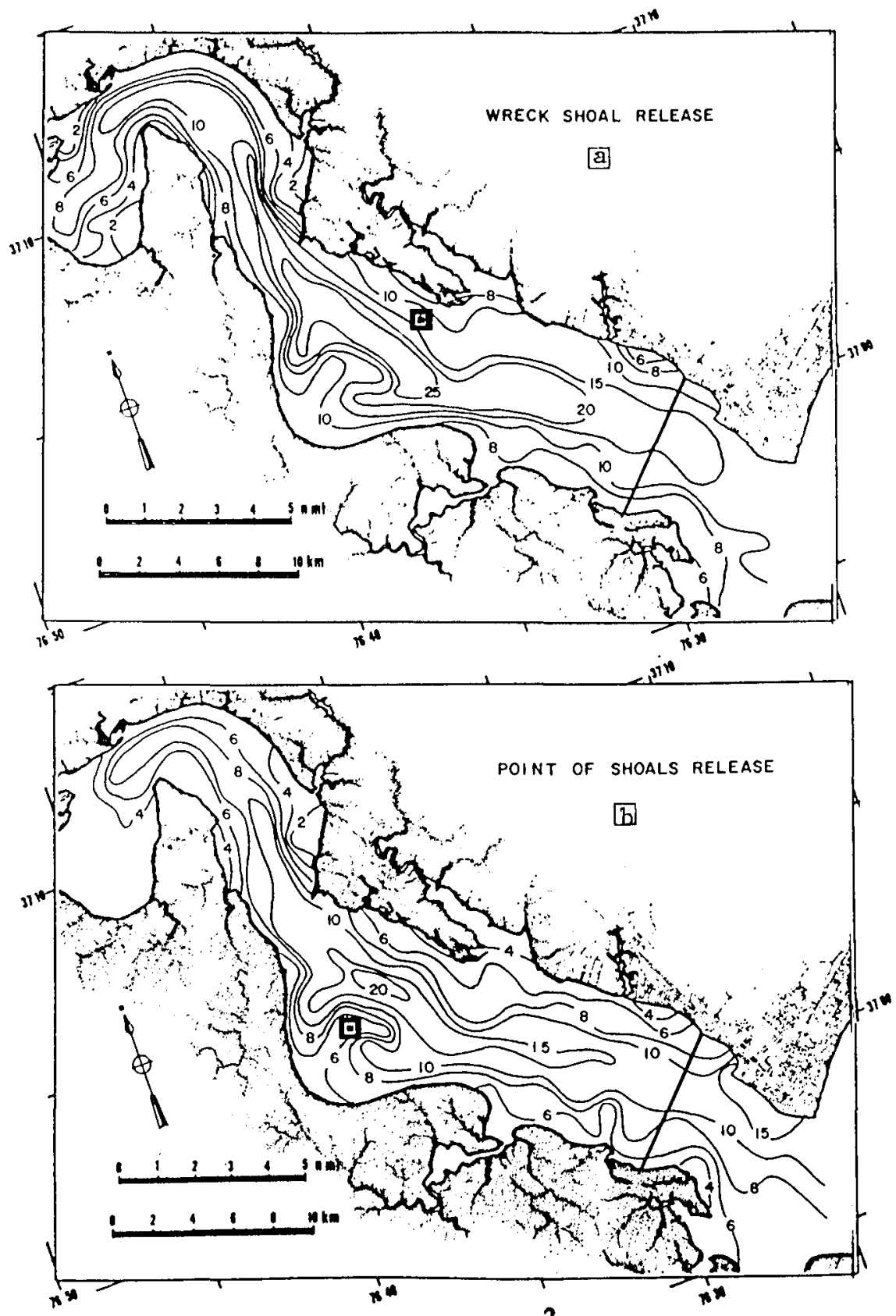

Figure 3. Isopleths of dye, as $\mathrm{mg} / \mathrm{m}^{2}$ in the water colunn 30 tidal cycles after releaso. a) upper b) lower 

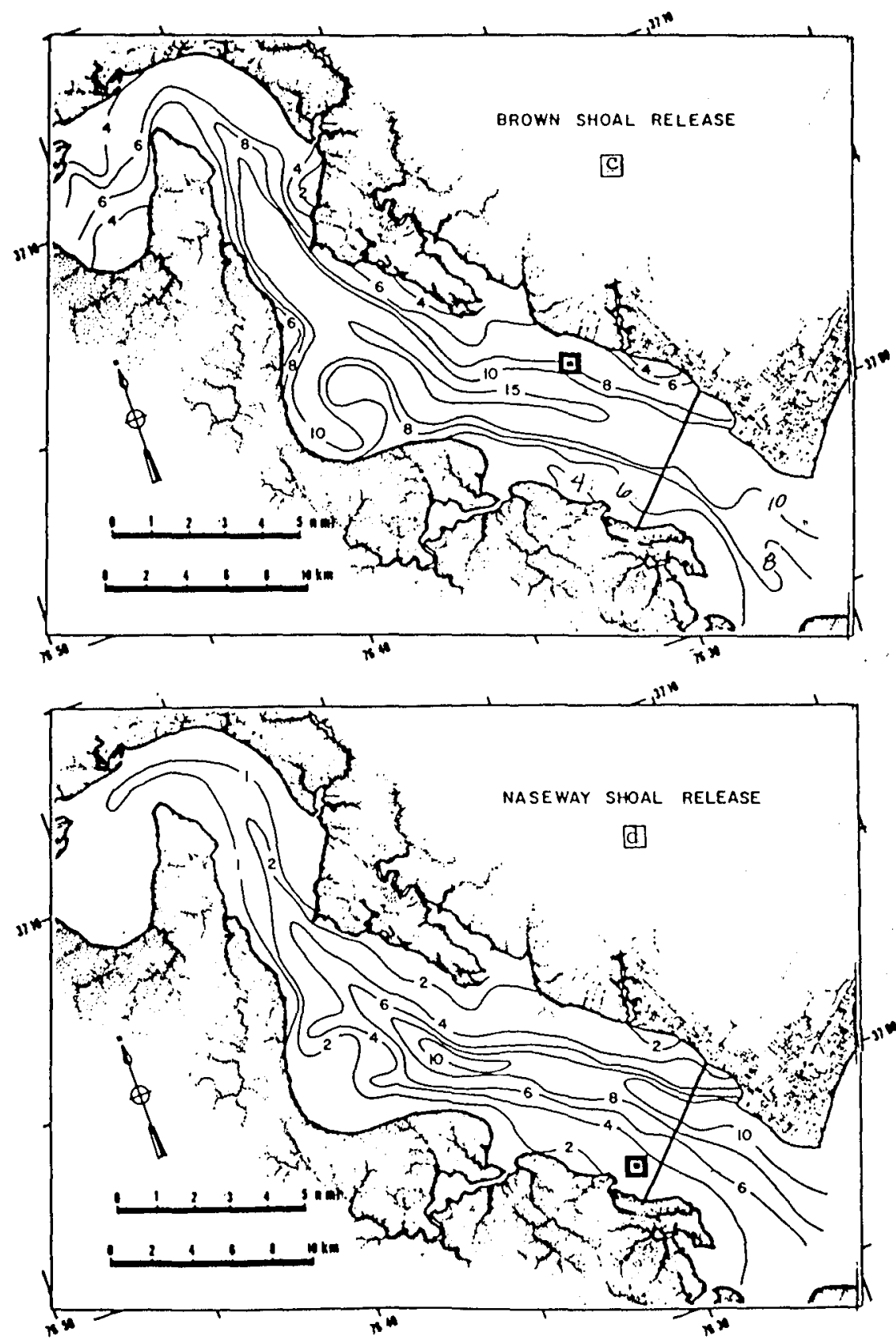

Figure 3 (continued)

c) upper d) lower 

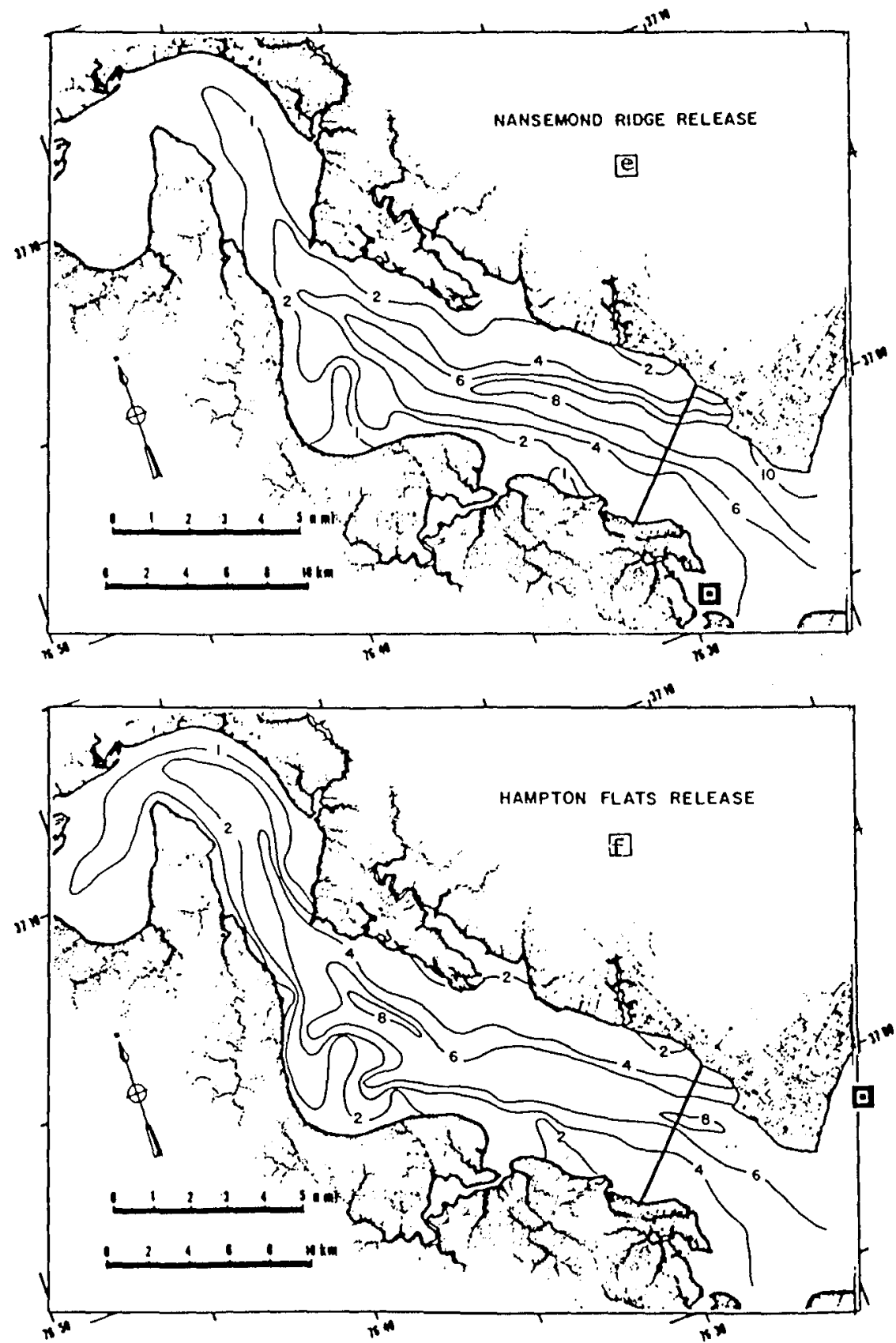

Figure 3 (continued)

-) upper f) lower 
Temporal Variations of Dyo Over Seed Oyster Bed Regions

The SPAT data set was used to examine temporal variations of dye (as $\mathrm{mg} / \mathrm{m}^{2}$ ) found over oach of the six public oyster rock regions shown in Figure 2 . Results of this analysis are shown In Figure 4 which consists of six subfigures, each representing a specific oyster rock region, and a copy of Figure 2. Each subfigure has six vertical panels which represent individual dye roloase points and show SBE (solid line) and SBF (dashed line) variations of dye per unit area from 10 to 20 days $(20$ to 40 tida cycles) after release. This analysis eliminates the bias introdnced in Figures 3 , a through $f$ due to greater water depths in channels and shows agrement with these figures in that the release at Wreck Shoal resulted in greatest quantities of dye over each oyster rock region.

Through 1 inear interpolation, the average quantity of dye over each oystor rock region 30 tidal cycles after release as woll as means and standard doviations of dye quantities over the rocks for the period 20 to 40 tidal cycles after roloase wero dotermined (Table I). Only s 1 ight differences existed between tho average concentrations and means for the 20-40 tidal cycle period maximum differences were $35 \%$ while the average difference was $1.6 \%$. Thus, concentrations on the 30 th tidal cycle after release provide a reasonable estimate of mean concentrations during the setting period. Information shown in Table I was used to rank the effectiveness of oach reloase point in providing dye to the seed bod regions and to rank the seed bed rogions with regard to receiving dye from the various release points (Table II). The best release points were those in the upstream portion of the model and on the northeastern shoals. All but the Prock Shoal and White Shoal seod oyster bed regions are excelient to moderately good locations for receiving dye from all release points.

\section{Dye Retention}

Results of our final inventory of dye have been arrangod according to retention in rogions of the mode1 in the following cascading order:

a) Primary seed oyster beds, 


\author{
Table I \\ Dyo Concontrations (as mg/m ${ }^{2}$ ) Over Solocted Sood Oyster \\ Rock Rogions From Str Candidate Brood Stock Areas
}

Tost I

Ro1.Point 1(Wreck Shoa1s) Re1.Point 2(Point of Shoals)

Avg for Cycles 20-40 Avg for Cycles 20-40

Sampling Rogion 30th cyc. Moan Std.Dev. 30th cyc. Mean Std.Dev.

$\begin{array}{lrrrrrr}\text { Point of Shoals } & 20.7 & 20.6 & 2.9 & 12.6 & 12.9 & 2.0 \\ \text { Wreck Shoals } & 15.9 & 16.0 & 2.3 & 10.2 & 10.4 & 1.4 \\ \text { White Shoa1s } & 13.1 & 13.1 & 2.5 & 8.2 & 8.3 & 1.2 \\ \text { Brown Shoa1 Reach } & 14.4 & 14.4 & 3.5 & 9.1 & 9.0 & 1.6 \\ \text { Naseway Shoa } & 13.4 & 13.2 & 2.6 & 9.2 & 9.0 & 1.5 \\ \text { Nansemond Ridge } & 10.8 & 10.4 & 3.0 & 8.2 & 8.1 & 2.1\end{array}$

Test II

Re1.Point 3(Naseway Shoa1s) Rel.Point 4(Brown Shoa1)

Cycles 21-39

Cycles 21-39

$\begin{array}{lrrrrrr}\text { Point of Shoals } & 4.9 & 4.7 & 0.8 & 11.2 & 11.3 & 2.0 \\ \text { Wreck Shoals } & 4.2 & 4.1 & 0.7 & 9.7 & 9.8 & 1.4 \\ \text { Whito Shoal } & 5.6 & 5.5 & 1.1 & 8.6 & 8.7 & 1.4 \\ \text { Brown Shoal Reach } & 5.8 & 5.9 & 1.3 & 10.0 & 10.3 & 1.3 \\ \text { Naseway Shoal } & 5.9 & 5.9 & 1.0 & 9.1 & 9.5 & 1.0 \\ \text { Nansomond Ridge } & 6.6 & 6.7 & 1.3 & 8.4 & 8.3 & 1.2\end{array}$

Test III

Re1.Point 5(Nansemond Ridge) Re1.Point 6(Hampton Flats)

Cycles 21-39 Cycles 21-39

$\begin{array}{lllllll}\text { Point of Shoals } & 4.3 & 4.2 & 0.9 & 5.6 & 5.6 & 0.7 \\ \text { Wreck Shoals } & 3.6 & 3.5 & 0.9 & 4.3 & 4.3 & 0.5 \\ \text { Whito Shoal } & 4.9 & 4.7 & 1.0 & 4.4 & 4.4 & 0.7 \\ \text { Brown Shoal Roach } & 5.0 & 4.9 & 1.1 & 4.6 & 4.5 & 0.6 \\ \text { Naseway Shoal } & 5.0 & 5.0 & 0.8 & 5.0 & 4.9 & 0.7 \\ \text { Nansemond Ridge } & 5.6 & 5.5 & 0.9 & 5.0 & 5.0 & 1.0\end{array}$


Tab1e II

A. Ranking of Release Points with Regard to delivery of Dye to Seed Bed Regions

$\begin{array}{ccl}\text { Ranking } & \text { Score } & \text { Release Point } \\ 1 & 30 & \text { Wreck Shoal } \\ 2 & 22 & \text { Brown Shoa 1 } \\ 3 & 20 & \text { Point of Shoa1s } \\ 4 & 10 & \text { Naseway Shoa 1 } \\ 5 & 4 & \text { Nansemond Ridge } \\ 5 & 4 & \text { Hampton F1ats }\end{array}$

B. Ranking of Seed Oyster Bed Regions With Regard to Receipt of Dye from all Resease Points

$\begin{array}{crl}\text { Ranking } & \text { Score } & \text { Seed Oyster Bed Regions } \\ 1 & 22 & \text { Point of Shoa1s } \\ 2 & 18 & \text { Naseway Shoa1 } \\ 3 & 17 & \text { Brown Shoa1 Reach } \\ 4 & 15 & \text { Nansemond Ridge } \\ 5 & 11 & \text { Vreck Shoa1 } \\ 6 & 7 & \text { White Shoa1 }\end{array}$

* Scoring assigned 5 points to highest concentration and 0 points to lowest for each of six dye releases.

Consistency in ranking of release points or seed oyster bed regions would have yielded scores of $30,24,18,12,6$ and 0 . 



\section{.}

Figure 4. Temporal variations in dye concentrations (as $\mathrm{mg} / \mathrm{m}^{2}$ ) over each of six seed oyster bed regions resulting from injection at six release points. 


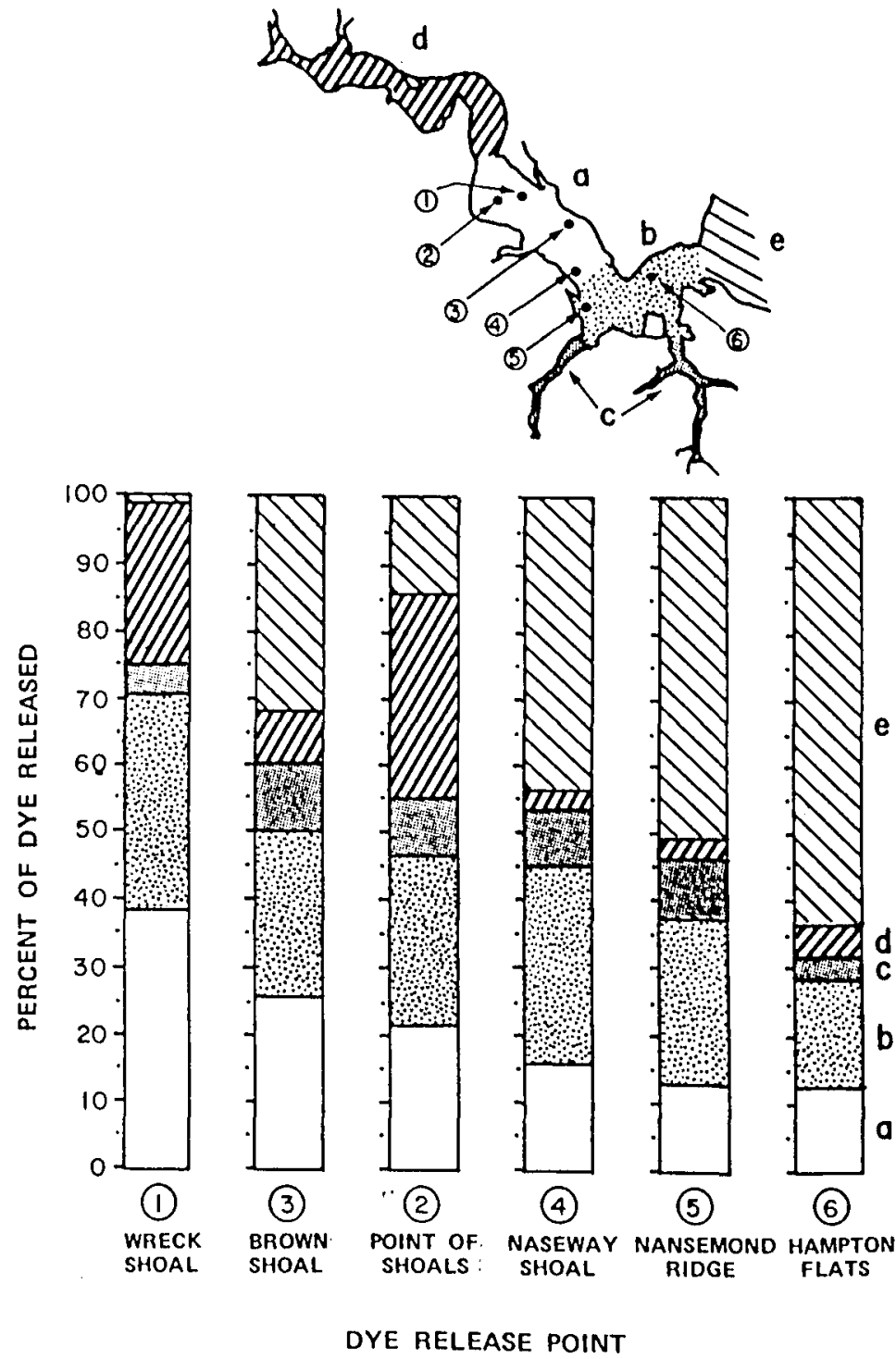

Figuro 5. Dye retention (as percent of initial reloase) in various portions of James River Hydraulic Model after completion of each test (40 tidal cycles) as determined from sampling each model segment. Rotention regions are: a) primary seod oyster beds b) Hampton Roads c) the Elizabeth and Nansemond Rivers d) fresher, npstream regions e) portion seaward of mouth of James. 
b) the historical1y important oystering reglons of Ilampton Roads near the river mouth,

c) largo downstream tributarios (the Elizabeth and Nansemond Rivers) whore oyster beds exist or conld be established if pollution wore reduced,

d) the low salinity portions of the system upstream of the seed oyster beds, and,

e) areas outside the mouth of the James River.

These results (Figure 5) show that the Wreck Shoal release point provides best retention of dye within the desirable portion of the system while loss of dye from the James estuary is greatest (over 605) from the Hampton Flats release point. The Point of Shoals release location has the greatest upstream loss of dye (>30\%).

\section{General Circulation in the Model}

Temporal variations in dye distributions from the six release points and visual observations of dye movement were used to determine the general circulation in the James River hydraulic model under conditions of these experiments. The pattern is the generally expected movement of water in a 'weak' partially-mixed estuary, as described by Pritchard (1987). Additionally, we find indications of cross-stream transport of dye at oither end of the seod oyster regions. Extensive cross stream movement appeas to take place in Burwel1 Bay. Present information does not indicate whether this motion is diroct (i.o. 1aterally across this region) or results from movement along tho northeasternmost channel during a flooding tide and then downstream along the curving southwesterly channel during the ebbing tide thus giving the appearance of cross-stream motion this area. In either case, dye test results show a definite net cross stream transport in the Burwell Bay region.

Similar cross-strean transport of dye in the Ilampton Roads region is suggested by releases on the downstroam southwest shoals (Naseway Shoals and Nansomond Ridgo). Dye released at these locations was measurod in the Brown Shoal Reach sampling area within 20 cycles after release. Based on this interpretation of our results, we infer the general cyclonic circulation in the seod oystor area of the James estuary shown in Figure 6 . 


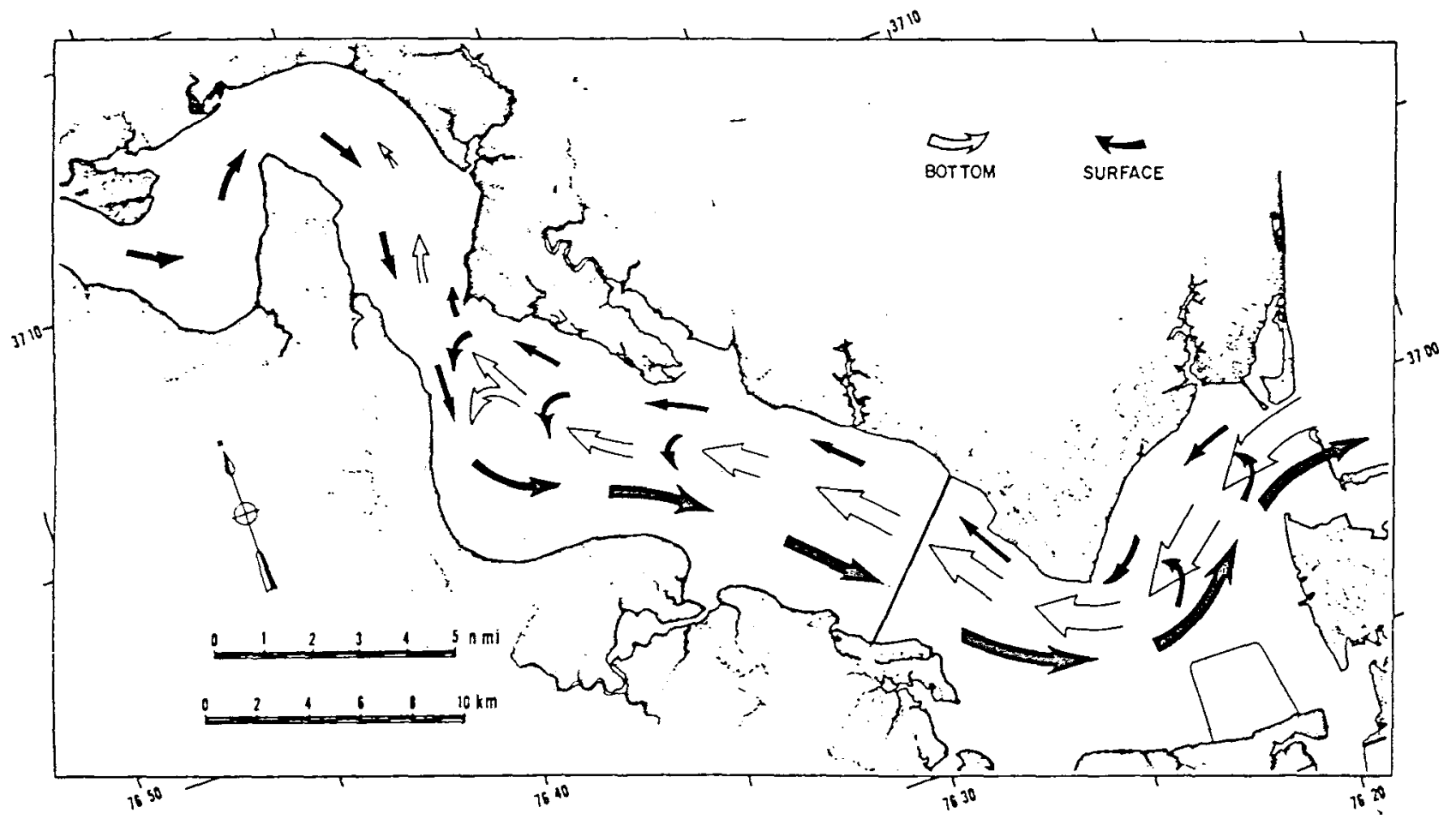



Figure 6. Hypothesized general surface and bottan circulation in the estuarine portion of the James River Hydraulic Model based on observed dye and measured concentrations. 


\section{SUMMARY AND CONCLUSTON}

Assuming that the James River hydraulic model properly mimicked the prototype and that dye particles simulate pelagic oyster larvac reasonably effectively, the following conclusions are possible:

1) The two-1ayered circulation concept for partially-mixod estuaries devoloped by Pritchard (1951, 1952 and 1953) appeared in our model dye tests. We noto that scaled hydraulic models which do not rotate (such as the James River Hydraulic Model) cannot properly reproduce Coriolis accolerations found in natural physical systems. However, the consequences of these accelerations - stronger upstream motion on the right side of a northern hemisphere estuary (when looking upstream) and greater downstrean motion on the opposite side - appear to have been properly introduced in the James model.

2) In the historical seed oystor-producing area of the James River Estuary an interesting circulatory pattern is noted. Water moving upstream on the northern side of tho estuary crosses over to the southern shore in the Burwell Bay region. Wator moving downstream along the southern shore crosses over to the opposite side of the estuary in the Hampton Roads area. Thus, a cyclonic pattern is establishod within tho estuary. Snspended particlos within this cyclonic circulation wonld tend to remain there for a wile and generally circulate within the system. Retention is not complete, however, as suspended material leaves the seed-oystor roach both upstream and downstream through advective and diffusive processes. Thirty-percent of the dye released at Wreck Shoal was lost to the upper reaches of the estuary and sixty percent of the dye released on Hampton Flats was lost to lower Chesapeake Bay.

3) Particles suspended in tho water column for a significant portion of the time wonld move with the water masses describod abovo. Oyster larvae, although able to swim relatively strongly in the 
vertical, move as the general horizontal circulation dictates. Thus, larvae originating in the seed-oyster producing region or arriving there from outside would tend to remain and cycle therein for a period. Those attaining their 15th day in viable condition would settle and attach provided suitable substrates were available. Those moving upstream and maturing to setting stage in the lower salinity environment would be lost to the system as would those exiting the James Estuary at the mouth. This cyclonic circulation pattern, with upstream and downstream losses shown by the model, corresponds to a combination of what Andrews (1983) describes as 'trap-type' and 'flushing-type' estuaries.

From the distribution of the dye in our modol experiments and the abundance and quantitios which reached the different historically productivo oyster rocks within the optimal 20-40 tidal cycle poriod we conclude that larvae originating around freck Shoal would remain over the most productive seed beds longer and in greater quantities. Thus spatfall and chance of survival to seed (and market) sizes would be best from this site. The Brown Shoal Reach would be next most productive of spat and seed whilo Point of Shoals would rank third.

Hampton Flats would rank fourth of all beds in spat and seed production but first of those beds in the lower estuary while larvao originating from brood stocks at Naseway Shoals and Nansomond Ridge would yield the fewest spat to the upriver seed beds.

Andrews (1983) concluded that during the period prior to 1960 (before spatfall and seed oyster production began to fail) the largest portion of viable larvae reaching the upriver-setting areas was produced downstream in the vicinity of Ilampton Flats (release point 6) and elsewhere in Hampton Roads, as woll as at the mouth of the James and nearby reaches of the lower Chesapeake. However, Haven, et al.., (1978), in discussing rodnced seed oyster production subsoquent to 1960 , state Other aspects are probably involved in keoping setting down...' and '... it is not possible to absolutely state that any single factor was responsible." Both concluded that the failure of setting began to occur when disease destroyed many of the mature 
oysters (brood stocks) on these more saline regions and when commercia 1 oyster plantors harvested the remaining plantings to reduce their economic losses.

Our results might seem contradictory but no such contradiction exists. Prior to the onslaught of disease, the down-estuary and lower Bay plantings of commercial oyster farmers wero massive, aggregating hundreds of thousands of bushels. They wero also older oysters and growth was faster there than on the soed oyster beds. Dyo introductions from the several release points were of the same volume and mass simulating equal numbers of larvac. Thus, the experiments did not address the quantitative effects of dye or larvae roleased from the several sites. An ordor of magnitude increase in downstream larval production (due to greater density of mature oysters and/or greater fecundity of individual oysters) would significantly alter these results.

If rapid replenishment of these prime seed-oyster producing reaches of the James Estuary by judicious placement of brood stock is the objective of a future management (repletion) effort, plantings should follow the rankings indicated above. If replacement by diseaseresistant spat is an objective, specially-bred brood stocks will have to be utilized. If disease-resistance or some other special1y-bred feature is judged not particularly desirable or necessary, other techniques such as quarantining of brood-stock in sanctuaries to allow endemic oysters to reach sexual maturity could also be considerod. Should survival in downstream areas of llampton Roads and the lower Chesapeake improve, encouragement of a renewal of downstream plantings by commercial lease-holders would be desirable also. Availability of disease-resistant oysters would encourage renewed planting even if the disease remains endemic.

\section{ACKNOWLEDGEMENTS}

We wish to thank M. S. Jablonsky for her many weeks of data processing, and $K$. Kiley for his substantial assistance with the averaging tochniques. Ho are also indebted to J.D. Andrews, D.S. Haven, C. Cerco and R. Mann for their comments on the manuscript and to $S$. Crossley, S. Sterling and B. Cauthorn for tts preparation. The dyo 
studies were funded by the Office of Water Resources Research under Contract NO, 14-01-001-1597, C-1214 and this analysis was funded by the Virginia Institute of Marine Scienco.

\section{REFERENCES}

Andrews, J. D. 1983 Transport of bivalve larvae in James River Virginia. J. She11fish Res. 3: 29-40.

Hargis, W. J., Jr. 1966 An evaluation of physical and biological offects of the proposed James river Navigation Project. Final report on result of operation Janos River, Virginia Institute of Marine Science Special Report in Applied Marine Science and Ocean Engineering. No $7,73 \mathrm{p}$.

llargis, W. J., Jr. 1969 Utilization of physical and mathematical models in marine water resources research, planning and management. A report for the period 1 Sept 1967-31 Dec 1968 to the Office of Water Resources Research, US Dept of Interior, Contract No 14-01-001-1597, C1214.

Haven, D. S., W. J. Hargis, Jr, and P. C. Kenda11. 1978 The Oyster Industry in Virginia. Special Papers in Harine Scienco of the Virginia Institute of Harino Science, No. 4. xlviii-1024.

Marsha11, N. B. 1954 Changes in the physiography of oyster bars in the James River. Va Proc Nat Shel1 $\mathrm{fish}$ Assoc. 45(1954):113-121.

Pritchard, D. W. 1951 The physical hydrography of estuaries and some applications to biological problems. Trans. 16th No. an. Hildlife Conforence. 368-376.

Pritchard, D. W. 1952 Salinity distribution and circulation in the Chesapeake Bay estuarine systom, Jour. Har. Res. 11:106-123.

Pritchard, D. W. 1953 Distribution of oyster 1arvae in relation to hydrographic conditions. Proc. Gulf and Caribbean Fishorios Institute 5 th Annual Session. Nov 1952. 123-132.

Pritchard, D. W. 1987 Estuarine classification - a holp or a hindrance. Included in this volume.

Ruzecki, E. P. and R. W. Moncure, 1969 Dye distribution resulting from point releases in the James River. Appendix IV in Hargis, W. J., Jr. 1969. Utilization of physical and mathematical models in marine water 
resources resoarch, planning and mangement, A report for the period 1 Sept 1967-31 Dec 1968 to the Office of Water Resources Research. US Dept of Interior.

Sampson, R. J. 1975 Surface II graphics System in Davis, $J$. C. and M. S. McCullagh, eds. Display \& Analysis of Spatial Data, John Hiley \& Sons, London, 244-266. United States Army Corps of Engineors. 1966 Effects of a proposed 35-foot channel to Richmond on currents and salinities over the seod oyster beds in the James River. Sumary Report of the vaterways Exporimont station, Vicksburg, Miss.

Wood, L, and W, J. Hargis, Jr. 1971 Transport of bivalve larvae in a tidal ostuary. in Crisp, D. J.ed.. Fourth Harine Biology Symposina, Cambridge Univ Press. 29-44. 